\title{
Using DEA method for determining tourism efficiency of Serbia and the surrounding countries
}

\author{
Ivana Ilić $^{1 *}$, Ivana Petrevska ${ }^{2}$ \\ ${ }^{1}$ University UNION - Nikola Tesla, Faculty for Strategic and Operational Management, \\ Belgrade \\ ${ }^{2}$ High School of Professional Studies for Educators and Business Informatics - Sirmijum, \\ Sremska Mitrovica
}

\begin{abstract}
Data Envelopment Analysis (DEA method) was used for determining tourism efficiency of Serbia and the surrounding countries. Analysis is done on the basis of input and output parameters which provide objective analysis and identify the best practice. Tourism expenses and the number of beds are used as inputs, while the number of arrivals, the number of nights spent and tourism revenue in 2016 are used as output parameters. The applied analysis has shown that in the aspect of tourism 6 countries are relatively efficient, while other 9 are relatively inefficient. The efficient countries are: Montenegro, Bosnia and Herzegovina, Croatia, Greece, Austria and Albania, while Serbia, FYR Macedonia, Slovenia, Romania, Bulgaria, Italy, Hungary, Slovakia and the Czech Republic have efficiency value of: $64.49 \%, 54.57 \%, 97.82 \%, 86.96 \%, 86.38 \%, 83.78 \%, 86.38 \%, 69.54 \%$, and $73.27 \%$, respectively. In order to improve their efficiency, the inefficient countries should reduce tourism costs and the number of beds and increase some of the output parameters. This paper should give the instructions to inefficient countries how to improve their efficiency.
\end{abstract}

Keywords: DEA method, tourism efficiency, analysis

JEL classification: Z32

\section{Korišćenje DEA metode u određivanju efikasnosti turizma Srbije i zemalja u okruženju}

Sažetak: Analiza obavijanja podataka (DEA metoda) korišćena je za određivanje efikasnosti turizma Srbije i zemalja u okruženju. Analiza je zasnovana na osnovnim ulaznim i izlaznim parametrima koji obezbeđuju objektivnu analizu i identifikuju najbolju praksu. Troškovi turizma i broj ležaja korišćeni su kao ulazni, dok su broj dolazaka, broj noćenja i prihod od turizma u 2016. godini korišćeni kao izlazni parametri. Primenjena analiza je pokazala da je u turističkom aspektu šest država relativno efikasno, dok su preostalih devet relativno neefikasne. Efikasne države su: Crna Gora, Bosna i Hercegovina, Hrvatska, Grčka, Austrija i Albanija, dok su Srbija, Makedonija, Slovenija, Rumunija, Bugarska, Italija, Mađarska, Slovačka i Češka efikasne 64,49\%, 54,57\%, 97,82\%, 86,96\%, 86,38\%, 83,78\%, 86,38\%, $69,54 \%$ i $73,28 \%$, respektivno. Kako bi popravile efikasnost, neefikasne zemlje bi trebalo da smanje troškove turizma i broj kreveta, a da povećaju neke od izlaznih parametara. Ovaj rad bi trebalo da da smernice neefikasnim državama kako da poboljšaju svoju efikasnost.

Ključne reči: DEA metoda, efikasnost turizma, analiza JEL klasifikacija: Z32

*ivana.ilic@fsom.edu.rs 


\section{Introduction}

The tourism sector is one of the largest and fastest growing industries in the world. Thanks to employees, revenues, investments and infrastructure development, the tourism sector gives a serious direct and indirect contribution to socio-economic development (Soysal-Kurt, 2017).

Efficiency is a basis of development, and tourism is an integral part of the economy of a state, so it is considered very important for both social and economic development of a certain country (Onetiu \& Predonu, 2013). Hadad et al. (2012) have concluded that large interest in measuring efficiency and productivity in tourism industry is not surprising, considering both the growing economic importance of tourism as a source of international revenue and employment, and increasing competition in the global tourist markets.

Efficiency is the relation of output and input parameters in general and refers to the operational performance of the firm (at micro level) or of the state (at macro level). The process that produces more outputs than inputs has bigger efficiency. If you can produce significantly more outputs than inputs, optimum efficiency will be achieved. Without the use of new technologies or the introduction of various changes, it is impossible to increase efficiency (Soysal-Kurt, 2017). Efficiency can be achieved using parametric and nonparametric methods. In parametric methods, the production function is predefined, and changes which can randomly affect production (factor analysis, regression analysis, etc.) are taken into consideration. In nonparametric methods, the analysis is carried out without prior definition of the production function, using linear programming (DEA method, artificial intelligence network, etc.) (Soysal-Kurt, 2017).

Toma (2014) has proven in her paper that DEA model can be used to evaluate the efficiency of tourism sector at regional level, which can offer additional information and indicate necessary decision making, in order to reach an optimal size of tourism market. The idea of this research is to evaluate tourism efficiency at national level and get the information that can be used as a guideline for the government when making long-term decisions concerning the future development of tourism.

In this paper, the data given in Table 1 were used to implement the DEA method used to measure tourism efficiency of Serbia and the surrounding countries. Tourist costs and the number of beds were used as input elements, while the number of arrivals, number of nights spent and tourism revenue were used as the output elements. It should also be noted that the DEA method was applied for 15 European countries (Serbia, FYR Macedonia, Montenegro, Bosnia and Herzegovina, Croatia, Slovenia, Romania, Bulgaria, Greece, Italy, Hungary, Austria, Slovakia, the Czech Republic and Albania) and that the data used as input and output parameters relate to 2016, as well as that they are taken from the official site of Eurostat database.

This paper consists of four parts. The first part gives an introduction to the research problem. The second part presents the methodological basis of the research, i.e. description of the DEA method. The third part presents the results, and the fourth part presents conclusions.

\section{Materials and methods}

Data capture analysis (DEA method) is a linear programming technique for measuring the performance of organizational units in which the presence of multiple input and output variables makes them difficult to be compared. Basically, the DEA method is designed to accept multiple different input and output parameters in order to determine the effectiveness of different decision-making units (DMUs). The obtained efficiency is relative because it is calculated within a predetermined set of decision units and the inclusion of a new decision- 
making unit or its exclusion in relation to the existing set can affect the change of results. In general, DEA method can be explained as a tendency to maximize the output parameters, while minimizing the input parameters (Rosić et al., 2015).

In chapter 12 of Avkiran (2006) book, Joseph Sarkis explained the rules that make sure that the basic productivity models are more discriminatory. Those rules have defined the optimal number of DMUs and input and output variables. The total number of DMUs should be either equal to or more than three times the sum of input and output variables. For example, if there are 2 inputs and 3 outputs (as in this case), the recommended minimum total number of DMUs should be 15 for some discriminatory power to exist in the model.

If we observe a system of $n$ decision-making units, in a system with $m$ inputs and different outputs, the efficiency in the DEA method is generally defined as the ratio of the weight of the output parameters and the weight of the input parameters that should be maximized according to the equation: (Rosić et al., 2015)

$$
E_{0}=\max \frac{\sum_{r=1}^{S} u_{r} y_{r 0}}{\sum_{i=1}^{m} v_{i} x_{i 0}}
$$

where $y_{r j}$ and $x_{i j}$ represent the $\mathrm{r}$-th output, $\mathrm{i}$-th input, and for the $\mathrm{j}$-th decision equation, i.e. the weight factor is assigned to the r-th output, i.e. the input. Efficiency is calculated for each decision-making unit separately with respect to these limitations in the sense that efficiency is always less than or equal to 1 , and weight factors are non-negative values (Rosić et al., 2015).

This equation can also be presented in the form of a linear programming task (Rosić et al., 2015):

Target function:

Limitations:

$$
\max E_{0}=\sum_{i=1}^{m} v_{i} x_{i 0}
$$

$$
\begin{gathered}
\sum_{r=1}^{s} u_{r} y_{r 0}=1 \\
\sum_{i=1}^{m} v_{i} x_{i j}-\sum_{r=1}^{s} u_{r} y_{r j} \leq 0, \text { uz uslov } u_{r}, v_{i} \geq 0, r=1, \ldots, s, i=1, \ldots, m
\end{gathered}
$$

The DEA method makes it easy to find weak decision-making units. Also, in this paper an input-oriented CRS model of the data capture analysis is used, which focuses on what should be the optimal input parameters that give certain output parameters.

\section{Results and discussion}

Table 1 presents statistical data on Serbia and the surrounding countries which were used as the base for the implementation of the DEA method using the CRS model.

Table 1: Statistical data on Serbia and the surrounding countries for 2016

\begin{tabular}{|l|r|r|r|r|r|}
\hline \multirow{2}{*}{$\begin{array}{c}\text { Name of } \\
\text { the country }\end{array}$} & \multicolumn{2}{|c|}{ Inputs } & \multicolumn{3}{c|}{ Outputs } \\
\cline { 2 - 6 } & $\begin{array}{c}\text { Tourism } \\
\text { costs } \\
\text { (in mil. } \\
\text { euro) }\end{array}$ & $\begin{array}{c}\text { Number of } \\
\text { beds }\end{array}$ & $\begin{array}{c}\text { Number of } \\
\text { arrivals }\end{array}$ & $\begin{array}{c}\text { Number of } \\
\text { nights spent }\end{array}$ & $\begin{array}{c}\text { Tourism } \\
\text { revenue } \\
\text { (in mil. } \\
\text { euro) }\end{array}$ \\
\hline Serbia & $1,085.0$ & $109,469.0$ & $2,753,591.0$ & $7,533,739.0$ & $1,040.0$ \\
\hline $\begin{array}{l}\text { FYR } \\
\text { Macedonia }\end{array}$ & 163.2 & $45,377.0$ & $737,182.0$ & $1,695,084.0$ & 226.4 \\
\hline Montenegro & 72.8 & $149,348.0$ & $1,813,817.0$ & $11,250,005.0$ & 782.4 \\
\hline
\end{tabular}


Ilić, I., Petrevska, I. - Using DEA method for determining tourism efficiency of Serbia and the surrounding countries - Hotel and Tourism Management, 2018, Vol. 6, No. 1: 73-80.

\begin{tabular}{|l|r|r|r|r|r|}
\hline $\begin{array}{l}\text { Bosnia and } \\
\text { Herzegovina }\end{array}$ & 171.2 & $27,096.0$ & $1,148,530.0$ & $2,376,743.0$ & 616.0 \\
\hline Croatia & 681.0 & $938,613.0$ & $15,446,591.0$ & $77,824,114.0$ & $7,954.0$ \\
\hline Slovenia & 822.0 & $113,157.0$ & $4,263,811.0$ & $11,057,731.0$ & $2,257.0$ \\
\hline Romania & $1,855.0$ & $326,098.0$ & $10,917,232.0$ & $25,274,649.0$ & $1,542.0$ \\
\hline Bulgaria & $1,006.0$ & $328,264.0$ & $7,196,397.0$ & $25,185,996.0$ & $2,838.0$ \\
\hline Greece & $2,038.0$ & $1,241,414.0$ & $23,713,777.0$ & $101,855,381.0$ & $14,126.0$ \\
\hline Italy & $22,013.0$ & $4,942,512.0$ & $116,887,879.0$ & $402,858,297.0$ & $35,555.0$ \\
\hline Hungary & $1,649.0$ & $446,000.0$ & $11,648,144.0$ & $29,291,168.0$ & $4,797.0$ \\
\hline Austria & $8,206.0$ & $1,001,442.0$ & $37,090,751.0$ & $117,957,253.0$ & $16,420.0$ \\
\hline Slovakia & $1,932.0$ & $183,903.0$ & $4,944,310.0$ & $13,894,782.0$ & $2,240.0$ \\
\hline $\begin{array}{l}\text { Czech } \\
\text { Republic }\end{array}$ & $3,970.4$ & $716,563.0$ & $18,388,853.0$ & $49,696,957.0$ & $5,632.8$ \\
\hline Albania & $1,139.0$ & 32,879 & 666,000 & $4,070,000$ & 1,528 \\
\hline
\end{tabular}

Source: Ministarstvo trgovine, turizma i telekomunikacija, 2017; Republički zavod za statistiku, 2017; Eurostat, 2017; The World Bank Data, 2018; Statistikat e turizmit, 2018

Tables 2 and 3 present the results of DEA method.

Table2: Efficiency results of Serbia and the surrounding countries for 2016

\begin{tabular}{|l|l|r|}
\hline DMU number & Name of the country & Efficiency \\
\hline 1 & Serbia & 0.64487 \\
\hline 2 & FYR Macedonia & 0.54574 \\
\hline 3 & Montenegro & 1.00000 \\
\hline 4 & Bosnia and Herzegovina & 1.00000 \\
\hline 5 & Croatia & 1.00000 \\
\hline 6 & Slovenia & 0.97820 \\
\hline 7 & Romania & 0.86955 \\
\hline 8 & Bulgaria & 0.86383 \\
\hline 9 & Greece & 1.00000 \\
\hline 10 & Italy & 0.83781 \\
\hline 11 & Hungary & 0.86379 \\
\hline 12 & Austria & 1.00000 \\
\hline 13 & Slovakia & 0.69539 \\
\hline 14 & Czech Republic & 0.73267 \\
\hline 15 & Albania & 1.00000 \\
\hline
\end{tabular}

Based on the results in Table 2, six countries are relatively efficient, while nine countries are relatively inefficient. Efficient countries that have a coefficient of efficiency 1 are: Montenegro, Bosnia and Herzegovina, Croatia, Greece, Austria and Albania. Inefficient countries have a coefficient of efficiency less than 1 (Serbia, FYR Macedonia, Slovenia, Romania, Bulgaria, Italy, Hungary, Slovakia and the Czech Republic). Based on the results of efficiency, we can see that the countries with the smallest coefficient efficiency are: FYR Macedonia $(0.54574$ or $54.574 \%)$, Serbia $(0.64487$ or $64.487 \%)$, Slovakia $(0.69539$ or $69.539 \%)$, the Czech Republic (0.73267 or $73.267 \%)$, Italy $(0.83781$ or $83.781 \%)$, Hungary $(0.86379$ or $86.379 \%)$, Bulgaria $(0.86383$ or $86.383 \%)$, Romania $(0.86955$ or $86.955 \%)$ and Slovenia $(0.97820$ or $97.820 \%)$.

In order to present the results in more detail, we have taken an example of Serbia and Bosnia and Herzegovina. One of the reasons for the inefficiency of Serbia in relation to Bosnia and Herzegovina can be the fact that the number of nights spent per bed in Serbia is 68.82, compared to Bosnia and Herzegovina where the number of nights spent per bed is 87.72 . 
Also, the number of arrivals per bed in Serbia is 25.15, while in Bosnia and Herzegovina it is 42.39. These parameters clearly show that Serbia cannot use its accommodation capacities the way Bosnia and Herzegovina can.

Table 3: Reference groups and $\lambda$ values of Serbia and the surrounding countries according to

\begin{tabular}{|l|c|c|c|c|c|c|}
\hline \multicolumn{1}{|c|}{ Countries } & $\begin{array}{c}\text { DMU } \\
\text { number }\end{array}$ & $\lambda$ & $\begin{array}{c}\text { DMU } \\
\text { number }\end{array}$ & $\lambda$ & $\begin{array}{c}\text { DMU } \\
\text { number }\end{array}$ & $\lambda$ \\
\hline Serbia & 4 & 0.959 & 12 & 0.045 & & \\
\hline FYR Macedonia & 4 & 0.469 & 5 & 0.013 & & \\
\hline Montenegro & 3 & 1.000 & & & & \\
\hline Bosnia and Herzegovina & 4 & 1.000 & & & & \\
\hline Croatia & 5 & 1.000 & & & & \\
\hline Slovenia & 4 & 2.436 & 12 & 0.044 & 15 & 0.024 \\
\hline Romania & 4 & 8.325 & 5 & 0.041 & 12 & 0.019 \\
\hline Bulgaria & 4 & 2.463 & 5 & 0.190 & 12 & 0.039 \\
\hline Greece & 9 & 1.000 & & & & \\
\hline Italy & 4 & 21.755 & 5 & 2.052 & 12 & 1.623 \\
\hline Hungary & 4 & 7.555 & 5 & 0.192 & & \\
\hline Austria & 12 & 1.000 & & & & \\
\hline Slovakia & 4 & 1.434 & 12 & 0.089 & & \\
\hline Czech Republic & 4 & 9.762 & 5 & 0.128 & 12 & 0.140 \\
\hline Albania & 15 & 1.000 & & & & \\
\hline
\end{tabular}

Reference groups which provide suggestions how to ensure the efficiency of inefficient countries and $\lambda$ values are shown in Table 3 . Based on the reference groups given in Table 3, the most heterogeneous countries are: Bosnia and Herzegovina (10 times), Austria (8 times), Croatia (7 times) and Albania (2 times). Thanks to countries in reference groups of inefficient countries and $\lambda$ values, efficient input and output parameters can be recalculated. In our DEA analysis, we have used input-oriented CRS model and the real and targeted values of input and output parameters of the results are shown in Tables 4 and 5.

Table 4: Real and target values of the input parameters of Serbia and the surrounding countries

\begin{tabular}{|l|r|r|r|r|}
\hline \multirow{2}{*}{ Name of the country } & \multicolumn{2}{|c|}{ Real input parameters } & \multicolumn{2}{c|}{ Target input parameters } \\
\cline { 2 - 5 } & $\begin{array}{c}\text { Tourism costs } \\
\text { (in mil. euro) }\end{array}$ & $\begin{array}{c}\text { Number } \\
\text { of beds }\end{array}$ & $\begin{array}{c}\text { Tourism costs } \\
\text { (in mil. euro) }\end{array}$ & $\begin{array}{c}\text { Number of } \\
\text { beds }\end{array}$ \\
\hline Serbia & $1,085.0$ & 109,469 & 529.7 & 70,593 \\
\hline FYR Macedonia & 163.2 & 45,377 & 89.1 & 24,764 \\
\hline Montenegro & 72.8 & 149,348 & 72.8 & 149,348 \\
\hline Bosnia and Herzegovina & 171.2 & 27,096 & 171.2 & 27,096 \\
\hline Croatia & 681.0 & 938,613 & 681.0 & 938,613 \\
\hline Slovenia & 822.0 & 113,157 & 804.1 & 110,690 \\
\hline Romania & $1,855.0$ & 326,098 & $1,613.0$ & 283,560 \\
\hline Bulgaria & $1,006.0$ & 328,264 & 869.0 & 283,564 \\
\hline Greece & $2,038.0$ & $1,241,414$ & $2,038.0$ & $1,241,414$ \\
\hline Italy & $22,013.0$ & $4,942,512$ & $18,442.6$ & $4,140,865$ \\
\hline Hungary & $1,649.0$ & 446,000 & $1,424.4$ & 385,249 \\
\hline Austria & $8,206.0$ & $1,001,442$ & $8,206.0$ & $1,001,442$ \\
\hline Slovakia & $1,932.0$ & 183,903 & 975.0 & 127,883 \\
\hline Czech Republic & $3,970.4$ & 716,563 & $2,909.0$ & 525,004 \\
\hline Albania & $1,139.0$ & 32,879 & $1,139.0$ & 32,879 \\
\hline
\end{tabular}


Ilić, I., Petrevska, I. - Using DEA method for determining tourism efficiency of Serbia and the surrounding countries - Hotel and Tourism Management, 2018, Vol. 6, No. 1: 73-80.

Table 5: Real and target values of the output parameters of Serbia and the surrounding countries

\begin{tabular}{|l|r|r|r|r|r|r|}
\hline \multirow{2}{*}{$\begin{array}{l}\text { Name of the } \\
\text { country }\end{array}$} & \multicolumn{4}{|c|}{ Real output parameters } & \multicolumn{3}{|c|}{ Target output parameters } \\
\cline { 2 - 7 } & $\begin{array}{c}\text { Number of } \\
\text { arrivals }\end{array}$ & $\begin{array}{c}\text { Number } \\
\text { of nights } \\
\text { spent }\end{array}$ & $\begin{array}{c}\text { Tourism } \\
\text { revenue } \\
\text { in mil. } \\
\text { euro) }\end{array}$ & $\begin{array}{c}\text { Number of } \\
\text { arrivals }\end{array}$ & $\begin{array}{c}\text { Number } \\
\text { of nights } \\
\text { spent }\end{array}$ & $\begin{array}{l}\text { Tourism } \\
\text { revenue } \\
\text { (in mil. } \\
\text { euro) }\end{array}$ \\
\hline Serbia & $2,753,591$ & $7,533,739$ & $1,040.0$ & $2,753,591$ & $7,533,739.0$ & $1,322.1$ \\
\hline $\begin{array}{l}\text { FYR } \\
\text { Macedonia }\end{array}$ & 737,182 & $1,695,084$ & 226.4 & 737,182 & $2,114,333$ & 391.1 \\
\hline Montenegro & $1,813,817$ & $11,250,005$ & 782.4 & $1,813,817$ & $11,250,005$ & 782.4 \\
\hline $\begin{array}{l}\text { Bosnia and } \\
\text { Herzegovina }\end{array}$ & $1,148,530$ & $2,376,743$ & 616.0 & $1,148,530$ & $2,376,743$ & 616.0 \\
\hline Croatia & $15,446,591$ & $77,824,114$ & $7,954.0$ & $15,446,591$ & $77,824,114$ & $7,954.0$ \\
\hline Slovenia & $4,263,811$ & $11,057,731$ & $2,257.0$ & $4,439,569$ & $11,057,731$ & $2,257.0$ \\
\hline Romania & $10,917,232$ & $25,274,649$ & $1,542.0$ & $10,917,232$ & $25,274,649$ & $5,774.1$ \\
\hline Bulgaria & $7,196,397$ & $25,185,996$ & $2,838.0$ & $7,196,397$ & $25,185,996$ & $3,662.3$ \\
\hline Greece & $23,713,777$ & $101,855,381$ & $14,126.0$ & $23,713,777$ & $101,855,381$ & $14,126.0$ \\
\hline Italy & $116,887,879$ & $402,858,297$ & $35,555.0$ & $116,887,879$ & $402,858,297$ & $56,375.1$ \\
\hline Hungary & $11,648,144$ & $29,291,168$ & $4,797.0$ & $11,648,144$ & $32,925,439$ & $6,183.8$ \\
\hline Austria & $37,090,751$ & $117,957,253$ & $16,420.0$ & $37,090,751$ & $117,957,253$ & $16,420.0$ \\
\hline Slovakia & $4,944,310$ & $13,894,782$ & $2,240.0$ & $4,944,310$ & $13,894,782$ & $2,343.0$ \\
\hline $\begin{array}{l}\text { Czech } \\
\text { Republic }\end{array}$ & $18,388,853$ & $49,696,957$ & $5,632.8$ & $18,388,853$ & $49,696,957$ & $9,333.4$ \\
\hline Albania & 666,000 & $4,070,000$ & 1,528 & 666,000 & $4,070,000$ & 1,528 \\
\hline
\end{tabular}

The percentages of potential improvement of the input and output values are shown in Table 6.

Table 6: Potential improvements in the input and output parameters of tourism in Serbia and the surrounding countries

\begin{tabular}{|l|r|r|r|r|r|}
\hline \multirow{2}{*}{$\begin{array}{c}\text { Name of the } \\
\text { country }\end{array}$} & \multicolumn{2}{|c|}{ Input parameters } & \multicolumn{3}{c|}{ Output parameters } \\
\cline { 2 - 6 } & $\begin{array}{c}\text { Tourism } \\
\text { costs } \\
(\%)\end{array}$ & $\begin{array}{c}\text { Number of } \\
\text { beds } \\
(\boldsymbol{\%})\end{array}$ & $\begin{array}{c}\text { Number of } \\
\text { arrivals } \\
(\boldsymbol{\%})\end{array}$ & $\begin{array}{c}\text { Number of } \\
\text { nights spent } \\
(\%)\end{array}$ & $\begin{array}{c}\text { Tourism } \\
\text { revenue } \\
(\%)\end{array}$ \\
\hline Serbia & -51.18 & -35.51 & 0.00 & 0.00 & +27.13 \\
\hline FYR Macedonia & -45.40 & -45.43 & 0.00 & +24.73 & +72.75 \\
\hline Montenegro & 0.00 & 0.00 & 0.00 & 0.00 & 0.00 \\
\hline Bosnia and & 0.00 & 0.00 & 0.00 & 0.00 & 0.00 \\
Herzegovina & 0.00 & 0.00 & 0.00 & 0.00 & 0.00 \\
\hline Croatia & -2.18 & -2.18 & +4.12 & 0.00 & 0.00 \\
\hline Slovenia & -13.05 & -13.04 & 0.00 & 0.00 & $+274,45$ \\
\hline Romania & -13.62 & -13.62 & 0.00 & 0.00 & +29.05 \\
\hline Bulgaria & 0.00 & 0.00 & 0.00 & 0.00 & 0.00 \\
\hline Greece & -16.22 & -16.22 & 0.00 & 0.00 & +58.56 \\
\hline Italy & -13.62 & -13.62 & 0.00 & +12.41 & +28.91 \\
\hline Hungary & 0.00 & 0.00 & 0.00 & 0.00 & 0.00 \\
\hline Austria & -49.53 & -30.46 & 0.00 & 0.00 & +4.60 \\
\hline Slovakia & $-26,73$ & -26.73 & 0.00 & 0.00 & +65.70 \\
\hline Czech Republic & 0.00 & 0.00 & 0.00 & 0.00 & 0.00 \\
\hline Albania & & & & & \\
\hline
\end{tabular}

According to the data given in Table 6, in order to make tourism in Serbia efficient, it is necessary to reduce the costs of tourism from 1,085 to 529.7 million Euros and the number of beds from 109,469 to 70,593 , i.e. to reduce tourism costs and the number of beds for $51.18 \%$ and $35.51 \%$, respectively. Tourism costs should also be reduced in FYR Macedonia, 
Slovenia, Romania, Bulgaria, Italy, Hungary, Slovakia and the Czech Republic for $45.40 \%$; $2.18 \% ; 13.05 \% ; 13.62 \% ; 16.22 \% ; 13.62 \% ; 49.53 \%$ and $26.73 \%$, respectively, while the number of beds in these countries should be reduced for $45.43 \%$; $2.18 \% ; 13.04 \%$; $13.62 \%$; $16.22 \% ; 13.62 \% ; 30.46 \%$ and $26.73 \%$, respectively. According to the targeted values for output parameters, tourism revenue in Serbia should be increased from 1,040 million Euros to $1,322.1$ million Euros, or, in other words, for $27.13 \%$. Tourism revenue should also be increased in FYR Macedonia, Romania, Bulgaria, Italy, Hungary, Slovakia and the Czech Republic by $72.75 \% ; 274.45 \% ; 29.05 \% ; 58.56 \% ; 28.91 \% ; 4.6 \%$ and $65.7 \%$, respectively, while the number of nights spent should be increased in FYR Macedonia and Hungary by $24.73 \%$ and $12.41 \%$, while the number of arrivals should be increased in Slovenia by $4.12 \%$.

Bogetic et al. (2017) emphasized that the Republic of Serbia, according to its geographical characteristics, has the potential to develop tourism, and that as a key problem the insufficient attractiveness of offers is emphasized (according to statistical data, tourists usually spend only a few days in Serbia). In addition, Radović (2016) made a proposal in his paper that Serbia could develop rural tourism the way it has been developed in Slovenia. According to our analysis Slovenia is relatively inefficient country, but it has well developed rural tourism.

\section{Conclusion}

So far, efficiency analysis has been made for certain subcategories of the tourism sector, such as the provision of catering services, etc. In some studies, economic efficiency has also been taken into consideration. In this research, we carried out the assessment of tourism efficiency at the macro level, i.e. at the level of the state, using those basic characteristics which influence the efficiency of the tourism sector - tourist costs, the number of beds, tourism revenue, the number of arrivals and the number of nights spent. Based on the results of the CRS-DEA method, nine out of the 15 analyzed countries were identified as relatively inefficient (Serbia, FYR Macedonia, Slovenia, Romania, Bulgaria, Italy, Hungary, Slovakia and the Czech Republic).

However, it should be noted that the results of the efficiency obtained by applying the DEA method are relative measurements and that there are other controlled and uncontrolled factors, such as globalization, capital, cultural and natural resources, security, etc. which affect efficiency. Therefore, in order to perform a more efficient evaluation, it is necessary to consider other factors, as well. The conducted research does not provide final results on the tourism efficiency of the countries that were the subject of this analysis, but gives the basic guidelines on the input/output balance, according to given variables. Therefore, this paper can provide some guidance for resource allocation and local self-governments as well as for tourist organizations when making long-term decisions. It should also be noted that this research used only the CRS model of the DEA method and that using other DEA models might have yielded different results.

\section{References}

1. Avkiran, N. K. (Ed.) (2006). Productivity Analysis in the Service Sector with Data Envelopment Analysis. $3^{\text {rd }}$ edition. Queensland, Australia: The University of Queensland, UQ Business School. http://dx.doi.org/10.2139/ssrn.2627576

2. Bogetić, S., Bešić, C. \& Đorđević, D. (2017). Analiza potencijala domaćeg turizma u odnosu na globalne trendove i značaj za ekonomski razvoj Srbije [The analysis of domestic tourism potentials in relation to global trends and the importance for economic development of Serbia]. Menadžment u hotelijerstvu i turizmu, 5(1), 94104. 
3. Eurostat. (2017). Retreived Novembar 7, 2017 from http://ec.europa.eu/eurostat/data/database

4. Hadad, S., Hadad, Y., Malul, M. \& Rosenboim, M. (2012). The economic efficiency of the tourism industry: a global comparison. Tourism Economics, 18(5), 931-940. https://doi.org/10.5367/te.2012.0165

5. Ministarstvo trgovine, turizma i telekomunikacija. (2017). Informacija o turističkom prometu u Srbiji za period januar - januar 2017 [Information on Tourist Traffic in Serbia for the period January - January 2017]. Retreived Novembar 7, 2017 from http://mtt.gov.rs/sektori/sektor-za-turizam/korisne-informacije-turisticki-prometsrbija-kategorizacija

6. Onetiu, A. N. \& Predonu, A. M. (2013). Economic and Social Efficiency of Tourism. Procedia - Social and Behavioral Sciences, 92, 648-651. https://doi.org/10.1016/j.sbspro.2013.08.732

7. Radović, G. (2016). Razvoj ruralnog turizma u Sloveniji - moguće smernice Srbiji [Development of rural tourism in Slovenia - potential guidelines for Serbia]. Menadžment u hotelijerstvu i turizmu, 4(2), 103-111.

8. Republički zavod za statistiku. (2017). Statistički godišnjak Republike Srbije 2017 [Statistial Yearbook of the Republic of Serbia 2017]. Retreived January 12, 2018 from http://pod2.stat.gov.rs/ObjavljenePublikacije/G2017/pdf/G20172022.pdf

9. Rosić, M., Kukić, D. \& Božović, M. (2015). Primena analize obavijanja podataka (DEA) za ocenu rizika u bezbednosti saobraćaja [Application of Data Envelopment Analysis (DEA) to Evaluate Risk in Road Safety]. IV međunarodna konferencija „Bezbednost saobraćaja u lokalnoj zajednici" (pp. 231-241). Banja Luka. http://agrosym.kors.conforganiser.com/paper/view/3620\#.WuLrjxuFNdg

10. Soysal-Kurt, H. (2017). Measuring Tourism efficiency of European Countries by Using Data Envelopment Analysis. European Scientific Journal, 13 (10), 31-49. http://dx.doi.org/10.19044/esj.2017.v13n10p31

11. Statistikat e turizmit [Tourism statistics]. Retreived April 27, 2018 from http://www.mjedisi.gov.al/statistikat-e-turizmit/

12. The World Bank Data. Retreived March 19, 2018 from https://data.worldbank.org/indicator

13. Toma, E. (2014). Regional scale efficiency evaluation by input-oriented Data Envelopment Analysis of tourism sector. International Journal of Academic Research in Environment and Geography, 1(1), 15-20.

Received: 2 March 2018; Sent for revision: 18 March 2018; Accepted: 10 May 2018 